\title{
低エネルギー光子スペクトロメーターによる石炭及び フライアッシュ中の微量元素の放射化分析
}

\author{
鈴木 章悟， 平井 昭司®*
}

(1983 年 10 月 11 日受理)

\begin{abstract}
$100 \mathrm{keV}$ 以下の低エネルギー領域の $\mathrm{X}$ 線, $\gamma$ 線測定に有勃な平板型 Pure Ge 検出器による低エネル ギー光子スペクトロメーター (LEPS) を用いて, 石炭及びフライアッシュ中の微量元素の機器中性子 放射化分析を行った。陚料は NBS 標準物質の石炭 (SRM 1632a, SRM 1635) 及びフライフッシュ （SRM 1633a）を用いた。これらを武蔵工大炉で 5 分間及び 5 時間の照射を行い, 冷却時間を変えてそ れぞれ 2 回ずっ LEPS によりX線， $\gamma$ 線の測定を行った。約 30 元素の定量を行った結果，NBS の保 証值及び参照值の示されている元素については, 良く一致していた。 又同軸型 $\mathrm{Ge}(\mathrm{Li})$ 検出器による 線測定では検出できなかった銅，ネオジム，ガドリニウム，ホルミウム，ツリウムが定量できた。
\end{abstract}

\section{1 緒言}

近年, 環境試料中の微量元素の分析に 非破壊・多元 素・同時定量が可能となる機器中性子放射化分析法 (IN AA）が活用されてきている.一般に INAA では測定 に当たっては同軸型 $\mathrm{Ge}(\mathrm{Li})$ 検出器を用いた $\gamma$ 線ス ペクトロメーター (以下同軸型と略記) がよく用いられ て括り, $100 \mathrm{keV}$ 以下の低エネルギー領域の測定に有効 な平板型 Pure Ge 検出器を用いた低ェネルギー光子ス ペクトロメーター (LEPS) (以下平板型と略記) につ いては従来, 検出器が $\mathrm{Ge}(\mathrm{Li})$ 検出器に比べて高価な こと, X線と $\gamma$ 線との混在ェネルギー領域で検出する ので解析が複雑なこと, 計数に拈いて自己吸収の補正を しなくてはならないこと, 多くの核種は $100 \mathrm{keV}$ 以上 の $\gamma$ 線を放出することなどであまり多く使用されてい なかったが, この数年, 価格の低下並びにコンピュー ターの利用で平板型も放射化分析に利用され始めてい る(1) 5 ).

著者らは，環境試料の一つである石炭及び石炭燃焼 後の残留物であるフライアッシュ中の微量元素を NBS (National Bureau of Standards) 標準物質の石炭 (SRM 1632a, SRM 1635) 及びフライアッシュ (SRM 1633a) を用いて，同軸型 INAA とより約 50 元素を定量した 方法について 既に報告している6). 本研究では, 更に INAA の適用範囲の扗大並びに 分析に和ける信頼性の

* 武蔵工業大学原子力研究所：215 神奈川県川崎市 麻生区王禅寺 971
向上のため, 平板型 INAA による石炭及びフライアッ シュの分析について検討を行った.

$$
2 \text { 実験 }
$$

\section{1 試 料}

試料は NBS 標準物質, れき青炭 (SRM 1632a), 亜れき青炭 (SRM 1635) 及びフライアッシュ (SRM 1633a）を使用し，それぞれ凍結乾燥させた後シシカゲ ルを入れたデシヶーター内に保存したものから約 10〜 $80 \mathrm{mg}$ を精ひょらし，ポリェチレン袋に二重封入して分 析試料とした. 各試料とも重量を変化させて 7 種類作っ た.

比較標準試料は既報6)で報告したものと同様に汇紙に 溶夜を添加したもの又は粉末試料を用いた. 又試料と比 較標準試料とを同時に同一カプセルで照射しないで, ア ンチモンのフラックスモニターを用いて試料ごとに中性 子束の補正を行った.

\section{$2 \cdot 2$ 照射及び測定}

照射は生成核種の半減期により, 短時間及び長時間の 2 種類の条件で武蔵工大炉 (MITRR) (TRIGA-II 型, 最大熱出力 $100 \mathrm{~kW}$ ) で行った. 照射後, 試料の外側の ポリエチレン袋を新しいポリエチレン袋と交換し，測定 用試料とし, 冷却時間を变化させて 2 回ずつX線及び $\gamma$ 線の測定を行った.

検出器は平板型 Pure Ge 検出器 (Canberra 社製 7150015 型, 表面積 $500 \mathrm{~mm}^{2}$, 厚さ $15 \mathrm{~mm}$, ベリリウム 
の空の厚さ $0.15 \mathrm{~mm}$ ) であり, 半值幅は ${ }^{55} \mathrm{Fe} 5.9 \mathrm{keV}$ 並びに ${ }^{57} \mathrm{Co} 122 \mathrm{keV}$ でそれぞれ $320 \mathrm{eV}, 577 \mathrm{eV}$ であ る.これにスペクトロスコピーアンプ (Canberra 社製 2020 型) と 4096 チャンネルのマルチチャンネル波高分 析器 (Canberra 社製 4203 型) を接続してX 線及び $\gamma$ 線の測定を行った.

検出器の遮へい体は外側から厚さ $60 \mathrm{~mm}$ の鉄材, 厚 さ $2 \mathrm{~mm}$ のカドミウム板, 厚さ $10 \mathrm{~mm}$ の無酸素銅板, 更に厚さ $5 \mathrm{~mm}$ のアクリル板の順となり, 内容積 $250 \times$ $250 \times 350 \mathrm{~mm}^{3}$ になっている. 更に遮へい体の上部全面 とクライオスタットの底 $\left(600 \times 600 \mathrm{~mm}^{2}\right)$ には厚さ 50 $\mathrm{mm}$ の鉛ブロックを敷いた。測定試料は検出器の上部 10〜30 mm のところにアクリル製の台を設け，その下面 に粘着テープで試料をはり付けた. 測定を行ったエネル ギー範囲は $5 \mathrm{keV}$ から $200 \mathrm{keV}$ あるいは $400 \mathrm{keV}$ ま
でとし，0.1 keV 当たり1チャンネルとした.

測定された平板型のスペクトルは GAMA システム7) を用いて，最小二乗法によるピークフィッティングを主 体とした解析方法8) により定量した. Table 1 に定量に 用いた核種並びにその半減期と注目したX線, $\gamma$ 線ピー クのエネルギー值及び照射条件，測定条件を示す.

照射・測定は注目する核種により短時間照射グループ I，II 並びに長時間照射グループ III，IVに分けた. 短 時間照射のグループI は気送管（熱中性子束密度 $1.5 \times$ $\left.10^{12} \mathrm{n} \mathrm{cm}^{-2} \mathrm{~s}^{-1}\right)$ て 5 分間照射し, $4 \sim 30$ 分冷却後測定 し, コバルト, ウラン, ヨウ素, バリウム, ジスプロシ ウム, セシウム, 臭素, ユウロピウムの 8 元素を定量し た. Fig. 1 に SRM 1632a れき青炭 (30.2 mg) の X 線及び $r$ 線スペクトルを示す. 気送管 5 分照射後, 14 分冷却し, 25 分測定したものである. ${ }^{60} \mathrm{mCo},{ }^{80 \mathrm{mBr}}$,

Table 1 Measurement conditions and nuclear data

\begin{tabular}{|c|c|c|c|c|c|}
\hline Group & Irradiation and counting conditions & Element & Nuclide & Half-life & $\mathrm{X}$-ray and $\gamma$-ray energies $(\mathrm{keV})$ \\
\hline \multirow[t]{8}{*}{ I } & Thermal neutron flux of $1.5 \times 10^{12}$ & Co & $60 \mathrm{~m}$ Co & $10.5 \mathrm{~min}$ & $(6.93) \dagger($ Co $K \alpha), 58.6(\gamma)$ \\
\hline & $\mathrm{n} \mathrm{cm}^{-2} \mathrm{~s}^{-1}$ & $\mathrm{U}$ & $239 \mathrm{U}$ & $23.5 \mathrm{~min}$ & $74.7(\gamma)$ \\
\hline & Irradiation time for $5 \mathrm{~min}$ & I & $128 I$ & $25.0 \mathrm{~min}$ & $27.4(\mathrm{Te} \mathrm{K} \alpha)$ \\
\hline & Cooling time for $4 \sim 30 \mathrm{~min}$ & $\mathrm{Ba}$ & ${ }^{139} \mathrm{Ba}$ & $82.9 \mathrm{~min}$ & $165.8(\gamma)$ \\
\hline & Counting time for $15 \sim 25 \mathrm{~min}$ & Dy & ${ }^{165} \mathrm{Dy}$ & $2.33 \mathrm{~h}$ & $46.7\left(\right.$ Ho $\left.\mathrm{K} \alpha_{2}\right), 47.5\left(\right.$ Ho $\left.\mathrm{K} \alpha_{1}\right), 94.7(\gamma)$ \\
\hline & & Cs & $134 \mathrm{mCs}$ & $2.90 \mathrm{~h}$ & $30.9(\mathrm{Cs} \mathrm{K} \alpha), 127.5(\gamma)$ \\
\hline & & $\mathrm{Br}$ & $80 \mathrm{~m} B \mathrm{Br}$ & $4.42 \mathrm{~h}$ & $11.9(\operatorname{Br~K} \alpha), 37.1(\gamma)$ \\
\hline & & $\mathrm{Eu}$ & $152 \mathrm{mEu}$ & $9.3 \mathrm{~h}$ & $39.5\left(\mathrm{Sm} \mathrm{K} \alpha_{2}\right), 40.1\left(\mathrm{Sm} \mathrm{K} \alpha_{1}\right), 121.8(\gamma)$ \\
\hline \multirow[t]{4}{*}{ II } & Flux of $1.5 \times 10^{12} \mathrm{n} \mathrm{cm}^{-2} \mathrm{~s}^{-1}$ & $\mathrm{Cu}$ & ${ }^{64} \mathrm{Cu}$ & $12.7 \mathrm{~h}$ & $7.47(\mathrm{Ni} \mathrm{K} \alpha)$ \\
\hline & Irradiation time for $5 \mathrm{~min}$ & & & & \\
\hline & Cooling time for $18 \sim 30 \mathrm{~h}$ & & & & \\
\hline & Counting time for $0.4 \sim 4 \mathrm{~h}$ & & & & \\
\hline \multirow[t]{7}{*}{ III } & Flux of $3.2 \times 10^{12} \mathrm{n} \mathrm{cm}^{-2} \mathrm{~s}^{-1}$ & W & ${ }^{187} \mathrm{~W}$ & $23.9 \mathrm{~h}$ & $61.1\left(\operatorname{Re~K} \alpha_{1}\right), 134.2(\gamma)$ \\
\hline & Irradiation time for $5 \mathrm{~h}$ & Ho & ${ }^{166} \mathrm{Ho}$ & $26.8 \mathrm{~h}$ & $80.6(\gamma)$ \\
\hline & Cooling time for $3 \sim 8 \mathrm{~d}$ & $\mathbf{L a}$ & ${ }^{140} \mathrm{La}$ & $40.3 \mathrm{~h}$ & $34.7\left(\mathrm{Ce} \mathrm{K} \alpha_{1}\right)$ \\
\hline & Counting time for $1 \sim 10 \mathrm{~h}$ & $\mathrm{Sm}$ & ${ }^{153} \mathrm{Sm}$ & $46.8 \mathrm{~h}$ & $40.9\left(\mathrm{Eu} \mathrm{K} \alpha_{2}\right), 41.5\left(\right.$ Eu K $\left.\alpha_{1}\right), 69.7(\gamma), 103.2(\gamma)$ \\
\hline & & Cd & ${ }^{115} \mathrm{Cd}$ & $2.23 \mathrm{~d}$ & $24.1(\operatorname{In} \mathrm{K} \alpha)$ \\
\hline & & $\mathrm{U}$ & ${ }^{239} \mathrm{~Np}$ & $2.35 \mathrm{~d}$ & $14.3\left(\mathrm{Pu} \mathrm{L} \alpha_{1}\right), 106.1(\gamma)$ \\
\hline & & $\mathrm{Hg}$ & ${ }^{197} \mathrm{Hg}$ & $2.67 \mathrm{~d}$ & $68.8\left(\mathrm{Au} \mathrm{K} \alpha_{1}\right), 77.4(\gamma)$ \\
\hline \multirow[t]{18}{*}{ IV } & Flux of $3.2 \times 10^{12} \mathrm{n} \mathrm{cm}^{-2} \mathrm{~s}^{-1}$ & $\mathrm{Lu}$ & ${ }^{177} \mathrm{Lu}$ & $6.71 \mathrm{~d}$ & $113.0(\gamma), 208.4(\gamma)$ \\
\hline & Irradiation time for $5 \mathrm{~h}$ & $\mathrm{Nd}$ & ${ }^{147} \mathrm{Nd}$ & $11.0 \mathrm{~d}$ & $91.1(\gamma)$ \\
\hline & Cooling time for $15 \sim 50 \mathrm{~d}$ & $\mathrm{Ba}$ & ${ }^{131} \mathrm{Ba}$ & $12.0 \mathrm{~d}$ & $30.9(\mathrm{Cs} \mathrm{K} \alpha), 123.7(\gamma)$ \\
\hline & Counting time for $10 \sim 40 \mathrm{~h}$ & Th & ${ }^{233} \mathrm{~Pa}$ & $27.0 \mathrm{~d}$ & $(13.5)\left(\mathrm{U} \mathrm{L} \alpha_{1}\right), 98.4\left(\mathrm{U} \mathrm{K} \alpha_{1}\right)$ \\
\hline & & $\mathrm{Cr}$ & ${ }^{51} \mathrm{Gr}$ & $27.7 d$ & $(4.95)(\mathrm{V} \mathrm{K} \alpha), 320.1(\gamma)$ \\
\hline & & $\mathrm{Yb}$ & ${ }^{169} \mathrm{Yb}$ & $32.0 \mathrm{~d}$ & $(50.7)\left(\mathrm{Tm} \mathrm{K} \alpha_{1}\right), 63.1(\gamma), 198.0(\gamma)$ \\
\hline & & $\mathrm{Ce}$ & ${ }^{141} \mathrm{Ce}$ & $32.5 \mathrm{~d}$ & $145.4(\gamma)$ \\
\hline & & Hf & ${ }^{181} \mathrm{Hf}$ & $42.4 \mathrm{~d}$ & $133.0(\gamma)$ \\
\hline & & $\mathrm{Fe}$ & ${ }^{59} \mathrm{Fe}$ & $44.6 \mathrm{~d}$ & $192.3(\gamma)$ \\
\hline & & & ${ }^{55} \mathrm{Fe}$ & 2.60 years & $(5.90)(\mathrm{Mn} \mathrm{K} \alpha)$ \\
\hline & & $\mathrm{Tb}$ & ${ }^{160} \mathrm{~Tb}$ & $72.1 \mathrm{~d}$ & $46.0\left(\mathrm{Dy} \mathrm{K} \alpha_{1}\right), 86.8(\gamma)$ \\
\hline & & $\mathrm{T}_{\mathbf{a}}$ & ${ }^{182} \mathrm{Ta}$ & $115.0 \mathrm{~d}$ & $67.7(\gamma), 100.3(\gamma)$ \\
\hline & & $\mathrm{Se}$ & ${ }^{75} \mathrm{Se}$ & $118.5 \mathrm{~d}$ & $136.0(\gamma)$ \\
\hline & & $\mathrm{Te}$ & $123 \mathbf{m} \mathbf{T e}$ & $119.7 \mathrm{~d}$ & $27.4(\mathrm{Te} \mathrm{K} \alpha)$ \\
\hline & & $\mathrm{T}_{\mathbf{m}}$ & ${ }^{170} \mathrm{Tm}$ & $128.6 \mathrm{~d}$ & $84.3(\gamma)$ \\
\hline & & Gd & ${ }^{153} \mathrm{Gd}$ & $241.6 \mathrm{~d}$ & $97.5(\gamma), 103.2(\gamma)$ \\
\hline & & $\mathrm{Zn}$ & ${ }^{65} \mathrm{Zn}$ & $244.1 \mathrm{~d}$ & $(8.04)(\mathrm{Cu} \mathrm{K} \alpha)$ \\
\hline & & Eu & ${ }^{152} \mathbf{E u}$ & 13.1 years & $39.5\left(\mathrm{Sm} \mathrm{K} \alpha_{2}\right), 40.1\left(\mathrm{Sm} \mathrm{K} \alpha_{1}\right), 121.8(\gamma)$ \\
\hline
\end{tabular}




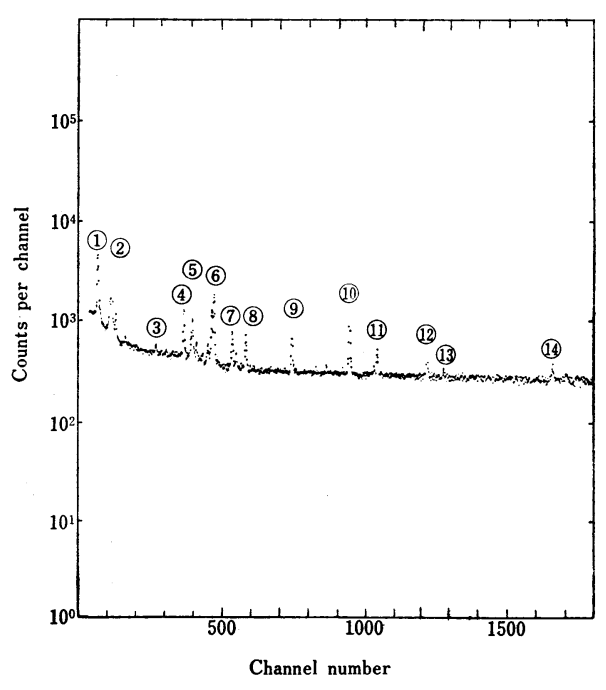

Fig. $1 \mathrm{X}$-Ray and $\gamma$-ray spectrum of bituminous coal SRM 1632a

Irradiation time : $5 \mathrm{~min}$, Thermal neutron flux : $1.5 \times$ $10^{12} \mathrm{n} \mathrm{cm}^{-2} \mathrm{~s}^{-1}$, Cooling time : $14 \mathrm{~min}$, Counting time: $25 \mathrm{~min}$, Sample weight: $30.2 \mathrm{mg}$; Peaks - (1) $6.9 \mathrm{Co} \mathrm{K \alpha}$ ( $\left({ }^{\circ} \mathrm{m} \mathrm{Co}\right)$, (2) $11.9 \mathrm{Br} \mathrm{K} \alpha \quad(80 \mathrm{mBr})$, (3) $27.4 \mathrm{Te} \mathrm{K} \alpha$ $\left({ }^{128} \mathrm{I}\right)$, (4) $37.180 \mathrm{mBr}$, (5) $40.1 \mathrm{Sm} \mathrm{K} \alpha(152 \mathrm{~m} \mathrm{Eu})$, (6) 47.5 Ho $\mathrm{K} \alpha\left({ }^{165} \mathrm{Dy}\right)$, (7) $53.8 \mathrm{Ho} \mathrm{K} \beta$ (165 Dy), (8) $58.660 \mathrm{~m} \mathrm{Co}$, (9) $74.7239 \mathrm{U}$, (10) $94.7165 \mathrm{Dy}$, (11) 104.3 ${ }^{155} \mathrm{Sm}$, (12) $121.8152 \mathrm{~m} \mathrm{Eu}$, (13) $127.5134 \mathrm{~m} \mathrm{Cs}$, (14) 165.8 ${ }^{139} \mathrm{Ba}$

${ }^{128} \mathrm{I},{ }^{152} \mathrm{mEu},{ }^{165} \mathrm{Dy},{ }^{239} \mathrm{U},{ }^{155} \mathrm{Sm},{ }^{134} \mathrm{~m} \mathrm{Cs},{ }^{139} \mathrm{Ba}$ が検出 された。

グループ II は ${ }^{64} \mathrm{Gu}$ を測定するために, グループ I の試料の一部について, $18 \sim 30$ 時間冷却後, 再び約 2 時 間測定した.

長時間照射のグループ III は中央実験管（熱中性子束 密度 $3.2 \times 10^{12} \mathrm{n} \mathrm{cm}^{-2} \mathrm{~s}^{-1}$ ) で 5 時間照射し, $3 \sim 8$ 日 冷却後測定し, タングステン, ホルミウム, ランタン, サマリウム, カドミウム, ウラン, 水銀の 7 元素を定量 した. 更にグループ IV として同一試料を照射後 15〜 50 日冷却後再び測定し，ルテチウム，ネオジム，バリウ ム, トリウム, クロム，イッテルビウム，七リウム， 八 フニウム, 鉄, テルビウム, タンタル, セレン, テルル， ツリウム, ガドリニウム, ユウロピウムの 16 元素を定 量した。

\section{3 自己吸収の補正}

低エネルギーのX線， $\boldsymbol{r}$ 線の測定では試料自身による 自己吸収が生じることから, 試料を構成している元素組 成, それらの質量吸収係数, 試料密度, 試料の厚さによ
り自己吸収の割合を補正しなくてはならない。

自己吸収の補正係数は式 (1) のように表すことがで きる3).

$$
f(E)=\frac{1-e^{-\mu_{\mathrm{m}}(E) \rho D}}{\mu_{\mathrm{m}}(E) \rho D}
$$

ここで $\mu_{\mathrm{m}}(E)$ : 質量吸収係数 $\left(\mathrm{cm}^{2} \mathrm{~g}^{-1}\right), E$ : 光子の エネルギー, $\rho:$ 密度 $\left(\mathrm{g} \mathrm{cm}^{-3}\right), D:$ 試料の厚み $(\mathrm{cm})$ である.

種々の物質が混合している試料の奏効的な $\mu_{\mathrm{m}}(E)$ は

$$
\mu_{\mathrm{m}}(E)=\sum_{i} \mu_{\mathrm{m}_{i}}(E) W_{i} / \sum_{i} W_{i}
$$

となる9).ここで, $W_{i}$ : 混合している各物質の重量, $\mu_{\mathrm{m}_{i}(E)}$ : 各物質の質量吸収係数 ${ }^{10)}$ である.

本研究に用いた試料は標準物質であり，元素組成が既 知であるため, 容易に $\mu_{\mathrm{m}}(E)$ を求めることができる. 試料の厚み $D$ は厳密に知ることが困難であるが, 拈拉 よその值について求めることができる.

Fig. 2 に $D=0.03 \mathrm{~cm}$ のときの各試料の自己吸収に よる減衰の割合を示す. 本分析の試料重量はわずかで, 厚みも薄いことから, $60 \mathrm{keV}$ 以上ではほとんど自己吸 収の影響を受けないが， $30 \mathrm{keV}$ 以下の低エネルギー領 域で急激に自己吸収の影響を受けるようになる。SRM

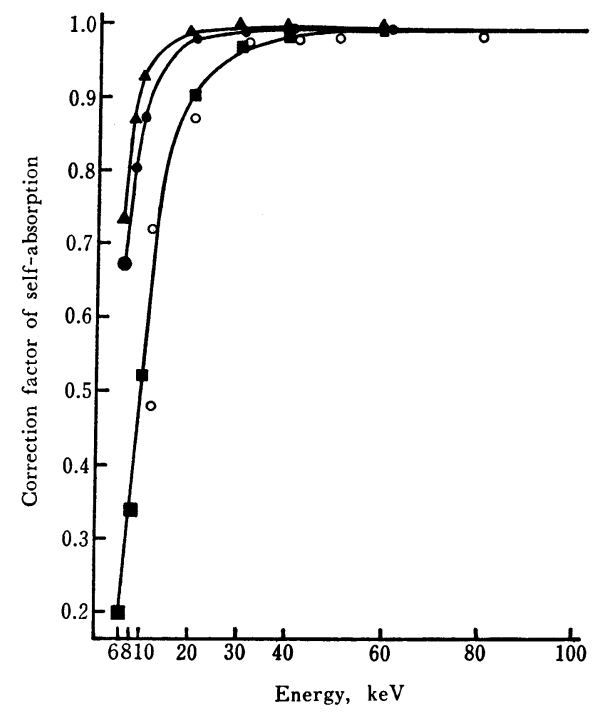

Fig. 2 Correction of self-absorption for coal and fly ash

: Calculated value for SRM 1632a coal, $\Delta$ : Calculated value for SRM 1635 coal, $\square$ : Calculated value for SRM 1633a fly ash, $O$ : Experimental value for SRM 1633a fly ash 
1633a フライアッシュには鉄などの重金属が多く含有 されていることから，自己吸収の割合は石炭よりかなり 大きくなっている. 又, SRM 1633a については照射し ていない試料の厚みを变化させて吸収体として検出器 上に置き， ${ }^{133} \mathrm{Ba},{ }^{152} \mathrm{Eu},{ }^{160} \mathrm{~Tb}$ の線源をその吸収体の上 方より鉛のコリメーターを通して透過させ，種々のエネ ルギーのX線, $\gamma$ 線に対する透過率を求めて, $\mu_{\mathrm{m}}(E) \rho$ を実験的に求めた ${ }^{3)}$. 結果を Fig. 2 に示すが式(1)の 結果とよく一致していた. このことにより Fig. 2 の曲 線を用いて自己吸収の補正を行った．更にこの方法によ り元素組成の不明な試料を分析する場合にも，実験的に 透過率を求めて自己吸収の補正を行うことができること になる。

\section{3 結果及び考察}

Table 2，3，4 にそれぞれ SRM 1632a，SRM 1635 及び SRM 1633a の分析結果を示す. 誤差は数回測定を 行った繰り返しの誤差を示す．検出されなかった元素に ついては検出限界を示す．又既報6) で報告した同軸型に

Table 2 Concentration of elements in bituminous coal SRM 1632a

\begin{tabular}{|c|c|c|c|}
\hline Element & $\begin{array}{l}\text { LEPS } \\
\text { this work } \\
\text { /ppm }\end{array}$ & $\begin{array}{c}\gamma \text {-Ray } \\
\text { spectrometer }{ }^{6)} \\
/ \mathrm{ppm}\end{array}$ & $\begin{array}{l}\text { NBS† } \\
\text { /ppm }\end{array}$ \\
\hline $\mathrm{Gr}$ & $34.4 \pm 2.4$ & $32.3 \pm 0.9$ & $34.4 \pm 1.5$ \\
\hline $\mathrm{Fe}$ & $10900 \pm 800$ & $11300 \pm 500$ & $11100 \pm 200$ \\
\hline Co & $6.1 \pm 0.4$ & $6.5 \pm 0.2$ & $(6.8)$ \\
\hline $\mathrm{Cu}$ & $15.4 \pm 1.9$ & $<120$ & $16.5 \pm 1.0$ \\
\hline $\mathrm{Se}$ & $2.7 \pm 0.4$ & $2.6 \pm 0.1$ & $2.6 \pm 0.7$ \\
\hline $\mathrm{Br}$ & $39 \pm 3$ & $38 \pm 1$ & \\
\hline Cd & $<1.10$ & $<0.34$ & $0.17 \pm 0.02$ \\
\hline $\mathrm{Te}$ & $<0.83$ & $<0.69$ & \\
\hline I & $2.0 \pm 0.3$ & $<1.7$ & \\
\hline Cs & $2.9 \pm 1.4$ & $2.3 \pm 0.1$ & $(2.4)$ \\
\hline $\mathrm{Ba}$ & $102 \pm 6$ & $104 \pm 5$ & \\
\hline $\mathrm{La}$ & $11.4 \pm 0.6$ & $10.7 \pm 0.4$ & \\
\hline $\mathrm{Ce}$ & $28 \pm 2$ & $29 \pm 1$ & (30) \\
\hline $\mathrm{Nd}$ & $14.2 \pm 2.0$ & $16.9 \pm 1.4$ & \\
\hline Sm & $3.1 \pm 0.3$ & $2.9 \pm 0.2$ & \\
\hline $\mathbf{E u}$ & $0.50 \pm 0.04$ & $0.50 \pm 0.06$ & $(0.5)$ \\
\hline Gd & $3.4 \pm 0.3$ & & \\
\hline $\mathrm{Tb}$ & $0.31 \pm 0.03$ & $0.26 \pm 0.02$ & \\
\hline Dy & $2.2 \pm 0.1$ & $2.4 \pm 0.2$ & \\
\hline Ho & $0.34 \pm 0.11$ & & \\
\hline$T_{m}$ & $0.38 \pm 0.04$ & & \\
\hline $\mathrm{Yb}$ & $1.19 \pm 0.06$ & $1.03 \pm 0.08$ & \\
\hline $\mathbf{L u}$ & $0.174 \pm 0.024$ & $0.21 \pm 0.02$ & \\
\hline Hf & $1.55 \pm 0.11$ & $1.53 \pm 0.5$ & $(1.6)$ \\
\hline $\mathrm{T} \mathbf{a}$ & $0.36 \pm 0.01$ & $0.35 \pm 0.02$ & \\
\hline$w$ & $0.79 \pm 0.02$ & $0.71 \pm 0.08$ & \\
\hline $\mathrm{Hg}$ & $0.169 \pm 0.065$ & $0.16 \pm 0.04$ & $0.13 \pm 0.03$ \\
\hline Th & $4.4 \pm 0.5$ & $4.1 \pm 0.1$ & $4.5 \pm 0.1$ \\
\hline $\mathrm{U}$ & $1.14 \pm 0.07$ & $1.25 \pm 0.06$ & $1.28 \pm 0.02$ \\
\hline
\end{tabular}

$\dagger$ Data from NBS certified values; Values in parentheses are information values only.
Table 3 Concentration of elements in subbituminous coal SRM 1635

\begin{tabular}{|c|c|c|c|}
\hline Element & $\begin{array}{l}\text { LEPS } \\
\text { this work } \\
\text { /ppm }\end{array}$ & $\begin{array}{c}\gamma \text {-Ray } \\
\text { spectrometer } \\
/ \text { ppm }\end{array}$ & $\begin{array}{l}\text { NBS† } \\
\text { /ppm }\end{array}$ \\
\hline $\mathrm{Cr}$ & $2.4 \pm 0.1$ & $2.6 \pm 0.3$ & $2.5 \pm 0.3$ \\
\hline $\mathrm{Fe}$ & $2180 \pm 170$ & $2340 \pm 140$ & $2390 \pm 50$ \\
\hline Co & $0.61 \pm 0.18$ & $0.62 \pm 0.06$ & $(0.65)$ \\
\hline $\mathrm{Cu}$ & $<4.8$ & $<46$ & $3.6 \pm 0.3$ \\
\hline $\mathrm{Se}$ & $0.97 \pm 0.03$ & $0.94 \pm 0.11$ & $0.9 \pm 0.3$ \\
\hline $\mathrm{Br}$ & $1.22 \pm 0.24$ & $1.07 \pm 0.17$ & \\
\hline $\mathrm{Cd}$ & $<0.45$ & $<0.38$ & \\
\hline $\mathrm{Te}$ & $<0.36$ & $<0.29$ & \\
\hline I & $<0.75$ & $<0.86$ & \\
\hline Cs & $<2.1$ & $0.053 \pm 0.006$ & \\
\hline $\mathrm{Ba}$ & $74 \pm 18$ & $77 \pm 24$ & \\
\hline La & $1.42 \pm 0.08$ & $1.38 \pm 0.07$ & \\
\hline $\mathrm{Ce}$ & $3.2 \pm 0.3$ & $3.4 \pm 0.2$ & $(3.6)$ \\
\hline $\mathrm{Nd}$ & $1.35 \pm 0.15$ & $<1.8$ & \\
\hline $\mathrm{Sm}$ & $0.33 \pm 0.06$ & $0.34 \pm 0.03$ & \\
\hline $\mathrm{Eu}$ & $0.061 \pm 0.005$ & $0.059 \pm 0.002$ & $(0.064)$ \\
\hline Gd & $0.44 \pm 0.06$ & & \\
\hline $\mathrm{Tb}$ & $0.050 \pm 0.004$ & $0.035 \pm 0.003$ & \\
\hline Dy & $0.35 \pm 0.04$ & $<0.74$ & \\
\hline Ho & $0.049 \pm 0.020$ & & \\
\hline $\mathrm{T}_{\mathrm{m}}$ & $0.063 \pm 0.010$ & & \\
\hline $\mathrm{Yb}$ & $0.179 \pm 0.016$ & $0.175 \pm 0.012$ & \\
\hline $\mathrm{Lu}$ & $0.033 \pm 0.014$ & $0.036 \pm 0.007$ & \\
\hline $\mathrm{Hf}$ & $0.30 \pm 0.03$ & $0.29 \pm 0.02$ & $(0.29)$ \\
\hline $\mathrm{Ta}$ & $0.045 \pm 0.009$ & $0.044 \pm 0.006$ & \\
\hline W & $0.21 \pm 0.05$ & $0.173 \pm 0.051$ & \\
\hline $\mathrm{Hg}$ & $<0.048$ & $0.035 \pm 0.011$ & \\
\hline $\mathrm{Th}$ & $0.56 \pm 0.03$ & $0.58 \pm 0.04$ & $0.62 \pm 0.04$ \\
\hline $\mathrm{U}$ & $0.22 \pm 0.02$ & $0.24 \pm 0.03$ & $0.24 \pm 0.02$ \\
\hline
\end{tabular}
$\dagger$ Data from NBS certifie
information values only.

よる分析結果と NBS の保証值及び参照値についても示 す. NBS の保証值及び参照值の示されている元素につ いて結果を比較すると, SRM 1632a のウラン及び SRM 1633a のセレンの值を除いて，いずれも誤差範囲内で良 く一致していた. 又同軸型の結果と比較すると全般に良 く一致していたが, SRM 1635 のテルビウム及び SRM 1633a のイッテルビウム, 七レンの值が多少高く, SRM 1632a のルテチウム及び SRM 1633a のネオジムの值が 多少低かった. これは同軸型では検出限界に近く誤差が 大きかったためと, 使用した比較標準試料に問題があっ たためではないかと思われる。

次に各々の元素について同軸型との分析感度の比較検 討を行う. 希土類のネオジム,ガドリニウム, ホルミウム， ツリウム, イッテルビウム, ルテチウムの分析に特いて は，それらの生成する核種の放出 $\gamma$ 線エネルギーが 100 $\mathrm{keV}$ 前後であるので, 高分解能の平板型では複合ピ ークが分離され検出できるようになった，例として， Fig. 3 に SRM 1633a フライアッシュ (20.4 mg) を 5 時間照射し，21〜22 日間冷却後, 約 14 時間測定した X線及び $\gamma$ 線スペクトルを示す. Fig. 3 (a) は平板型 
Table 4 Concentration of elements in coal fly ash SRM 1633a

\begin{tabular}{|c|c|c|c|}
\hline Element & $\begin{array}{l}\text { LEPS } \\
\text { this work } \\
\text { /ppm }\end{array}$ & $\begin{array}{c}\gamma-\mathrm{Ray} \\
\text { spectrometer } \\
/ \text { /ppm }\end{array}$ & $\begin{array}{l}\text { NBS } \dagger \\
/ \mathrm{ppm}\end{array}$ \\
\hline $\mathrm{Gr}$ & $193 \pm 14$ & $185 \pm 7$ & $196 \pm 6$ \\
\hline $\mathrm{Fe}$ & $97000 \pm 3000$ & $94000 \pm 3000$ & $94000 \pm 1000$ \\
\hline Co & $45 \pm 2$ & $44 \pm 1$ & $(46)$ \\
\hline $\mathrm{Cu}$ & $124 \pm 33$ & $<350$ & $118 \pm 3$ \\
\hline $\mathrm{Se}$ & $12.7 \pm 1.3$ & $10.2 \pm 0.6$ & $10.3 \pm 0.6$ \\
\hline $\mathrm{Br}$ & $<4.4$ & $2.2 \pm 0.3$ & \\
\hline Cd & $<2.4$ & $<1.4$ & $1.0 \pm 0.15$ \\
\hline $\mathrm{Te}$ & $<3.5$ & $<6.6$ & \\
\hline I & $<4.5$ & $<5.0$ & \\
\hline Cs & $11.8 \pm 3.2$ & $10.2 \pm 0.2$ & (11) \\
\hline $\mathrm{Ba}$ & $1300 \pm 90$ & $1210 \pm 50$ & $(1500)$ \\
\hline $\mathrm{La}$ & $66 \pm 2$ & $62 \pm 2$ & \\
\hline $\mathrm{Ce}$ & $170 \pm 6$ & $167 \pm 8$ & (180) \\
\hline $\mathrm{Nd}$ & $89_{ \pm 5}$ & $113 \pm 7$ & \\
\hline $\mathrm{Sm}$ & $21 \pm 1$ & $19.4 \pm 0.7$ & \\
\hline $\mathrm{Eu}$ & $3.9 \pm 0.3$ & $3.7 \pm 0.3$ & (4) \\
\hline Gd & $25 \pm 2$ & & \\
\hline $\mathrm{Tb}$ & $2.2 \pm 0.1$ & $2.1 \pm 0.1$ & \\
\hline Dy & $17.4 \pm 0.5$ & $16.8 \pm 0.3$ & \\
\hline Ho & $2.9 \pm 0.4$ & & \\
\hline $\mathrm{T}_{\mathrm{m}}$ & $2.4 \pm 0.1$ & & \\
\hline $\mathrm{Yb}$ & $8.3 \pm 0.7$ & $6.9 \pm 0.3$ & \\
\hline $\mathrm{Lu}$ & $1.33 \pm 0.10$ & $1.44 \pm 0.12$ & \\
\hline Hf & $7.6 \pm 0.3$ & $7.2 \pm 0.8$ & $(7.6)$ \\
\hline $\mathrm{T}_{\mathbf{a}}$ & $1.80 \pm 0.07$ & $1.71 \pm 0.05$ & \\
\hline W & $6.4 \pm 0.6$ & $5.9 \pm 0.4$ & \\
\hline $\mathrm{Hg}$ & $<0.29$ & $<0.42$ & $0.16 \pm 0.01$ \\
\hline $\mathrm{Th}$ & $25.0 \pm 0.7$ & $24.3 \pm 3.8$ & $24.7 \pm 0.3$ \\
\hline $\mathbf{U}$ & $9.7 \pm 0.8$ & $10.3 \pm 0.4$ & $10.2 \pm 0.1$ \\
\hline
\end{tabular}

$\dagger$ Data from NBS certified values; Values in parentheses are information values only.

のスペクトルであり, Fig. 3 (b) は同軸型のスペクトル である. 平板型ではこの $100 \mathrm{keV}$ 付近の検出効率は同 軸型の約 $1 / 2$ であるが，エネルギー分解能が約 2.6 倍 優れているため, 複雑に重なり合っているピークを分離 することができ, ${ }^{170} \mathrm{Tm} 84.3 \mathrm{keV},{ }^{147} \mathrm{Nd} 91.1 \mathrm{keV},{ }^{153} \mathrm{Gd}$ $103.2 \mathrm{keV},{ }^{177} \mathrm{Lu} 113.0 \mathrm{keV}$ 及び ${ }^{169} \mathrm{Yb} 130.5 \mathrm{keV}$ に 注目して定量を行うことができるようになった。 このた め, 同軸型では分析できなかったガドリニウム, ツリウ ムが分析できるようになった. 又ネオジム，イッテルビ ウム, ルテチウムについては検出限界が 1/1.5 1/2 程 度下がり，それだけ微量まで検出できるようになった。 更に平板型と同軸型を併用することにより,希土類 15 元 素のうち, エルビウム及び天然に存在しないプロメチウ ムを除いて，すべて微量ではあるが定量することがでさ た. エルビウムについては，分析に使用する ${ }^{171 \mathrm{Er}}$ が半 減期 7.5 時間で ${ }^{24} \mathrm{Na}$ の妨害を大きく受けるため検出で きなかった。

更に水銀とセレンとの分析に拈いても，平板型が分解 能が優れていることから容易に測定することができた. すなわち水銀に打いては, 同軸型では ${ }^{197} \mathrm{Hg}$ (半減期 2.67

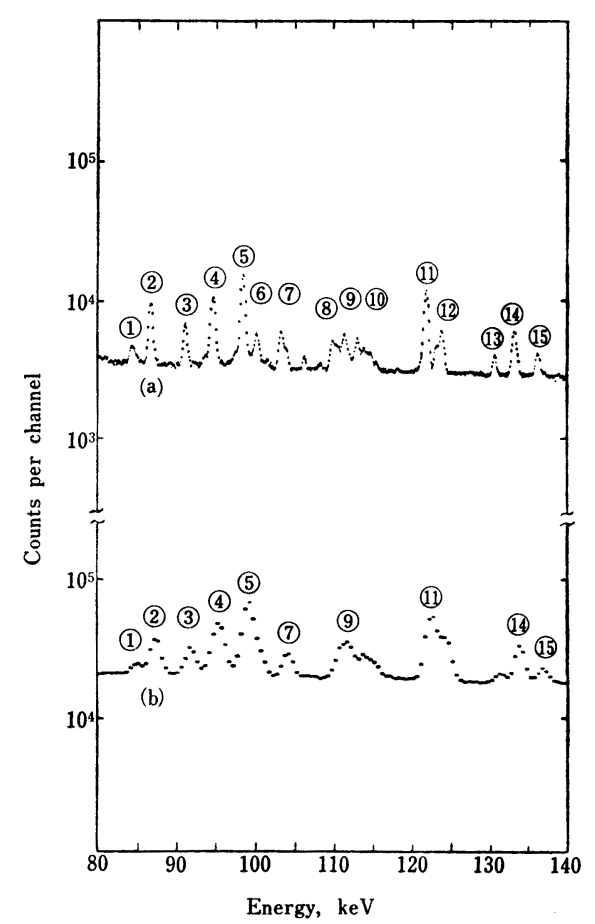

Fig. $3 \mathrm{X}$-Ray and $\gamma$-ray spectra of fly ash SRM $1633 \mathrm{a}$

Irradiation time $: 5 \mathrm{~h}$, Thermal neutron flux : $3.2 \times$ $10^{12} \mathrm{n} \mathrm{cm}^{-2} \mathrm{~s}^{-1}$, Cooling time : 21 22 d, Counting time : $14 \mathrm{~h}$, Sample weight $20.4 \mathrm{mg}$; (a) Planar pure Ge detector: Active area $500 \mathrm{~mm}^{2}$, Depth $15 \mathrm{~mm}$, FWHM $600 \mathrm{eV} \quad\left(122 \mathrm{keV} \quad{ }^{57} \mathrm{Co}\right), \quad 0.1 \mathrm{keV} /$ channel; (b) Coaxial $\mathrm{Ge}(\mathrm{Li})$ detector : Active volume $77 \mathrm{~cm}^{3}$, Relative efficiency $13.4 \%$, FWHM $1.4 \mathrm{keV}(122 \mathrm{keV}$ $\left.{ }^{57} \mathrm{Co}\right), 0.5 \mathrm{keV} /$ channel; Peaks : (1) $84.3 \mathrm{keV}{ }^{170} \mathrm{Tm}$, (2) $86.8{ }^{160} \mathrm{~Tb}$, (3) $91.11^{147} \mathrm{Nd}$, (4) $94.7 \mathrm{U} \mathrm{K} \alpha_{1}\left({ }^{23}{ }^{3} \mathrm{~Pa}\right)$, (5) $98.4 \mathrm{U} \mathrm{K} \alpha_{2}\left({ }^{233} \mathrm{~Pa}\right)$, (6) $100.3{ }^{182} \mathrm{Ta}$, (7) 103.2 ${ }^{153} \mathrm{Gd}$, (8) $109.8{ }^{169} \mathrm{Yb}$, (9) $111.3 \mathrm{U} \mathrm{K}_{\beta_{1}}\left({ }^{233} \mathrm{~Pa}\right)$, (10) $113.0{ }^{177} \mathrm{Lu}$, (11) $121.8{ }^{152} \mathrm{Eu}$, (12) $123.7^{131} \mathrm{Ba}$, (13) $130.5^{169} \mathrm{Yb}$, (14) $133.0^{181} \mathrm{Hf}$, (15) $136.0^{75} \mathrm{Se}$

日）の $68.8 \mathrm{keV}$ のX線ピークは ${ }^{153} \mathrm{Sm} 69.7 \mathrm{keV}$ の妨 害を受けて用いることができないので，検出感度が劣る ${ }^{203} \mathrm{Hg}$ (半減期 46.8 日) の $279.2 \mathrm{keV}$ を用いなければ ならない. しかし平板型では高分解能のため ${ }^{197} \mathrm{Hg}$ と ${ }^{153} \mathrm{Sm}$ とのピークを分離することが可能となり， ${ }^{203} \mathrm{Hg}$ に注目する場合よりは短い冷却時間で定量することが できた. SRM 1635 については ${ }^{24} \mathrm{Na}$ が高濃度であり， ${ }^{197} \mathrm{Hg}$ を検出できなかった.

セレンに拈いても, 同軸型では ${ }^{75} \mathrm{Se} 136.0 \mathrm{keV}$ のピー クは ${ }^{181 \mathrm{Hf}} 133.0 \mathrm{keV} ，{ }^{131 \mathrm{Ba}} 133.5 \mathrm{keV}$ などと複雑に 重なり合い, 解析が困難である. 又 ${ }^{75} \mathrm{Se} 264.7 \mathrm{keV}$ の ピークは ${ }^{182} \mathrm{Ta} 264.1 \mathrm{keV}$ との複合ピークとなり, タン タルが含有されている場合には $264.7 \mathrm{keV}$ のピークか 
らタンタルの奇与分を差し引いて定量する. しかし平板 型では ${ }^{75} \mathrm{Se} 136.0 \mathrm{keV}$ のピークが ${ }^{181} \mathrm{Hf} 133.0 \mathrm{keV}$ な どのピークと分離できるので簡単に定量することがで きる。

同軸型で測定する長寿命核種とともに，低エネルギー のX線, $\gamma$ 線を放出する短寿命核種が存在する場合には, 平板型を用いると，迅速な分析が可能となる．それらの 元素として先に述べた水銀の外コバルト，セシウム，ウ ラン,バリウムがある.コバルトの分析においては,同軸 型では ${ }^{60} \mathrm{Co}$ (半減期 5.27 年) $1173 \mathrm{keV}, 1332 \mathrm{keV}$ を用

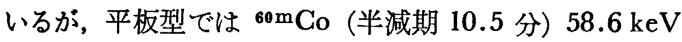
に注目して分析できた. セシウムもコバルト同様， ${ }^{134} \mathrm{Cs}$ (半減期 2.06 年) $604.7 \mathrm{keV}, 795.8 \mathrm{keV}$ を使用しない

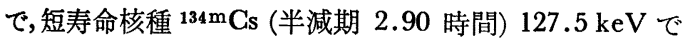
分析できた. ウランの分析では同軸型と同様, ${ }^{239} \mathrm{~Np}$ (半 減期 2.35 日) $106.1 \mathrm{keV}$ に注目しても分析できるが, 平板型では更に ${ }^{239} \mathrm{U}$ (半減期 23.5 分) $74.7 \mathrm{keV}$ で短 時間に精度良く分析できた。バリウムの分析に拈いて， 短寿命核種の ${ }^{139} \mathrm{Ba}$ (半減期 82.9 分) $165.8 \mathrm{keV}$ 及び 長寿命核種の ${ }^{131} \mathrm{Ba}$ (半減期 12.0 日) $123.7 \mathrm{keV}$ のど ららからも分析できたが, ${ }^{131 B a} に$ 注目した場合, ${ }^{131} \mathrm{Ba}$ からの $30.9 \mathrm{keV}$ の Cs $\mathrm{K}_{\alpha}$ 線は ${ }^{153} \mathrm{Sm} 40.9 \mathrm{keV}$ のX 線のエスケープピークと同じェネルギーであるので, サ マリウムが高濃度に含まれる石炭及びフライアッシュで は ${ }^{153} \mathrm{Sm}$ が減衰するまで十分に冷却した後に測定しなけ ればならない。

その他, Table 1 に示したように, 生成される核種に は, 同軸型で検出できる約 $100 \mathrm{keV}$ 以上のエネルギー の $\mathrm{X}$ 線， $r$ 線を放出する以外に，低いエネルギーの $\mathrm{X}$ 線 を放出する核種がある，それらに注目するとき注意しな ければならない元素が二, 三ある.

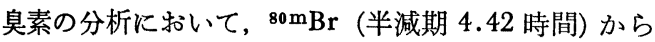
の $11.9 \mathrm{keV}$ の $\mathrm{Br} \mathrm{K}{ }_{\alpha}$ 線に注目した場合は ${ }^{82 \mathrm{~m}} \mathrm{Br}$ (半 減期 6.1 分）からも $\mathrm{Br} \mathrm{K}_{\alpha}$ 線が放出されるので, 冷却 時間を長くとらないと ${ }^{82 \mathrm{mBr}}$ の影響を受ける。

クロム, 鉄, 亜鉛の分析に打いて, ${ }^{51} \mathrm{Cr},{ }^{55} \mathrm{Fe}$ 及び ${ }^{65} \mathrm{Zn}$ はいずれも 4〜8 keV の低エネルギーのX線を放出する が，低エネルギーのため $\beta$ 線の制動放射によるバックグ ラウンドレベルが高く, かつこれら 3 元素のX線が重な り合って複合ピークとなる。このため解析が困難な場合

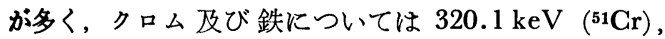
$192.3 \mathrm{keV}\left({ }^{59} \mathrm{Fe}\right)$ の $\gamma$ 線を用いて分析し, 帚鉛について は低エネルギーの $8.0 \mathrm{keV}\left({ }^{65} \mathrm{Zn}\right)$ のX線しか放出しな いので分析できなかった.

同軸型より平板型のほうが感度良く分析できた元素と
して，前述した希土類元素の外に銅がある．同軸型では ${ }^{66} \mathrm{Cu}$ (半減期 5.08 分)に注目するが，石炭及びフライア ッシュ中のアルミニウムの含有量が高いため, ${ }^{28} \mathrm{Al}$ の影 響により検出が困難となる，一方， ${ }^{64} \mathrm{Cu} に$ に注目した場合 は, $1364 \mathrm{keV}$ の $\gamma$ 線放出率が低く, 又 $511 \mathrm{keV}$ の $\beta^{+}$ 線では ${ }^{24} \mathrm{Na}$ など他の核種からの $\beta+$ 線及び電子対生成 からの $511 \mathrm{keV}$ の線と区別がつかず分析できない，し かし平板型では ${ }^{64} \mathrm{Cu}$ の $7.47 \mathrm{keV}$ の $\mathrm{Ni} \mathrm{K}{ }_{\alpha}$ 線を検出 することが可能となり，微小なピークではあるが，自己 吸収の補正を行って，定量することができた。この值は NBSの保証値と比較的よく一致した.

終わりに, 本研究を行うに当たり, 試料作製に協力い ただた武蔵工業大学原子力研究所の本多照幸助手に感 謝します.

\section{交献}

1) E. Cortes, L. Munoz, V. Cassorla : J. Radioanal. Chem., 59, 429 (1980).

2) M. S. Germani, I. Gokmen, A. C. Sigleo, G. S. Kowalczyk, I. Olmez, A. M. Small, D. L. Anderson, M. P. Failey, M. C. Gulovali, C. E. Choquette, E. A. Lepel, G. E. Gordon, W. H. Zoller : Anal. Chem., 52, 240 (1980).

3) P. Bode, M. D. Bruin, P. J. M. Korthoven : J. Radioanal. Chem., 64, 153 (1981).

4) 戸村健児：原子力工業，27 (12)，69 (1981)。

5) J. Holzbecher, D. E. Ryan : J. Radioanal. Chem., 74, 25 (1982).

6)鈴木章悟, 平井昭司: 分化, 31，443 (1982).

7) Y. Murata, S. Hirai, M. Okamoto, H. Kakihana : J. Radioanal. Chem., 36, 525 (1977).

8) 鈴木章悟, 平井昭司: 武蔵工業大学原子力研究所 年報，2，25(1980).

9) 武田健治, 本多哲太郎, 野口正安 : Radioisotopes, 28, 24 (1979).

10）野口正安：“ “線スペクトロメトリー”， p. 214 (1980),（日刊工業新聞社).

\section{拧}

Activation analysis of trace elements in coal and fly ash by low energy photon spectrometer. Shogo Suzuki and Shoji Hirai (Atomic Energy Research Laboratory, Musashi Institute of Technology, 971, Oozenji, Asao-ku, Kawasaki-shi, Kanagawa, 215)

A coaxial $\mathrm{Ge}(\mathrm{Li})$ detector (energy range of $100 \sim$ $3000 \mathrm{keV}$ ) is conventionally used for the analyses of many radioactive nuclides which emitted above $100 \mathrm{keV} \gamma$-rays. However, the measurement of low energy $\gamma$-rays and $\mathrm{X}$-rays (energy range of $10 \sim 200 \mathrm{keV}$ ) have the possibility to improve analytical sensitivity of some elements. This study describes an application of Low Energy Photon Spectrometer (LEPS) with a planar pure Ge detector to the determination of elements in coal and coal fly ash by instrumental neutron activation analysis. NBS standard material coal (SRM 1632a and SRM 1635) and coal fly ash (SRM 1633a) samples (ca. 10 80 mg) were irradiated for short time ( $5 \mathrm{~min})$ 
at a thermal neutron flux of $1.5 \times 10^{12} \mathrm{n} \mathrm{cm}^{-2} \mathrm{~s}^{-1}$ and for long time $(5 \mathrm{~h})$ at a thermal neutron flux of $3.2 \times$ $10^{12} \mathrm{n} \mathrm{cm}^{-2} \mathrm{~s}^{-1}$ in Musashi Institute of Technology Research Reactor (MITRR). Low energy $\gamma$-ray and $\mathrm{X}$-ray spectra for short time irradiation samples were measured for 15 25 min after $4 \sim 30 \mathrm{~min}$ of cooling and for $0.4 \sim 4 \mathrm{~h}$ after $18 \sim 30 \mathrm{~h}$ of cooling by a pure $\mathrm{Ge}$ detector $\left(500 \mathrm{~mm}^{2}\right.$ in area and $15 \mathrm{~mm}$ in depth) coupled with a 4096 channel multichannel analyzer. Gamma-ray and X-ray spectra ofr long time irradiation samples were measured for $1 \sim 10 \mathrm{~h}$ after $3 \sim 8 \mathrm{~d}$ of cooling and for $10 \sim 40 \mathrm{~h}$ after $15 \sim 50 \mathrm{~d}$ of cooling. The spectra obtained were analyzed with a peak-fitting procedure by a minicomputer system (GAMA system), and the effect of self-absorption of $\gamma$-ray and X-ray was corrected. As the results, 29 elements in coal and fly ash could be determined. The concentration of trace elements were in good agreement with NBS certified values. The analytical sensitivities of $\mathrm{Cu}, \mathrm{I}, \mathrm{Nd}, \mathrm{Gd}$, Dy, Ho, Tm, and Lu by the planar pure Ge detector were higher than those by the coaxial $\mathrm{Ge}(\mathrm{Li})$ detector.

(Received October 11, 1983)

\section{Keyword phrases}

instrumental neutron activation analysis of trace elements in coal and fly ash; low energy photon spectrometer with planar pure Ge detector; NBS standard reference material.

\title{
陽極酸化処理したグラッシーカーボン電極による クロルプロマジンの微量定量
}

\author{
潩村喜代子®，井上哲，楠 文代* \\ (1983 年 12 月 27 日受理)
}

\begin{abstract}
電気分析法によるクロルプロマジン (GPZ) の定量感度向上のために，グラッシーカーボン (GC) 電極の陽極酸化処理を試み, 定量に最適な処理条件を検討した. GGの処理は表面をアルミナで研磨し た後， $0.5 \mathrm{~mol} \mathrm{dm}^{-3}$ リン酸緩衝液（pH 6.7）中で $1.6 \mathrm{~V} v s . \mathrm{SCE}, 2$ 分間の定電位電解を行うのが最 適であったこの処理電極を用い，サイクリックボルタンメトリーにより CPZの定量を行ったところ， $\left(2 \times 10^{-7} \sim 4 \times 10^{-5}\right) \mathrm{mol} \mathrm{dm}^{-3}$ の範囲で $\mathrm{CPZ}$ 濃度と得られた酸化電流值との間に直線関係が成り立ち, 定量限界は $1 \times 10^{-7} \mathrm{~mol} \mathrm{dm}-3$, GPZ 濃度 $1.0 \times 10^{-5} \mathrm{~mol} \mathrm{dm}^{-3}$ における相対標準偏差は $3.5 \%$ 以 内であった。この GG の陽極酸化処理により，研磨のみの GC 電極に比べ GPZ の定量感度は約 30 倍向上し，生体試料分析などへの忍用が期待される. 陽極酸化処理に伴う電極㳖面の变化と GPZ の酸 化電流値増大との関係についても考察した.
\end{abstract}

\section{1 緒}

フェノチアジン系薬物の一種であるクロルプロマジン (CPZ) は向精神病薬として広く用いられている. GPZ の血中濃度と治療効果との関係はまだ十分明確ではない が, 血中薬物濃度のモニタリングに際しては数十〜数百 $\mathrm{ng} / \mathrm{ml}\left(10^{-7} \sim 10^{-6} \mathrm{~mol} \mathrm{dm}^{-3}\right)$ の $\mathrm{CPZ}$ の濃度の検出・ 定量が必要と考えられる1).

CPZ の定量法としては電子捕獲検出器を用いたガス

* 東京薬科大学：192-03 東京都八王子市堀之内 1432-1
クロマトグラフィー，此色法などが報告されている2)3． しかし前者は十分な感度を有しても試料の前処理が煩雑 であり，後者は簡易なスクリーニング法として有用であ っても検出感度が不十分である.

既報において著者らは,グラッシーカーボン (GC) 電 極を用いる CPZ のボルタンメトリーを行い, CPZ は 明りょらな陽極酸化ピークを与えること，その電極区応 に対してある種の陰イオンが接触効果を示すこと，を報 告した4).しかしこの方法によれば， CPZ の検出感度は $10^{-5} \mathrm{~mol} \mathrm{dm}{ }^{-3}$ 程度にとどまる. 又, 一般に固体電極は 使用中に電極特性が変動しやすく, 再現性のある分析値 